\title{
Molecular characterization and expression analysis of hepc 1 and hepc 2 in three tilapia species collected from Lake Manzala
}

\author{
Karima F. Mahrous", Heba A. M. Abd El - Kader, Dalia M. Mabrouk, Mohamad M. Aboelenin, Noha M. Osman, \\ Wagdy K. B. Khalil and Mohamed Saber Hassanane
}

\begin{abstract}
Background: Antimicrobial peptides were examined as an evolutionarily preserved component of the innate immune response and identified as a vital first-line defense against a broad spectrum of pathogens in fish. The objective of this study was to investigate the molecular characterization and expression analysis of hepc1 and hepc2 in three strains of tilapia species infected naturally in Lake Manzala.

Results: The results revealed that the alignment of nucleotide sequences including CDNA and deduced amino acid sequences showed that hepcidin 1 in Sarotherodon galilaeus has four genotypes due to SNPs in codon $34^{\text {Gln }}$ (CAG)/Leu (CTG) and codon 36 Glu (GAA/GAG). Regarding hepcidin 2 gene, different genotypes were detected in Tilapia

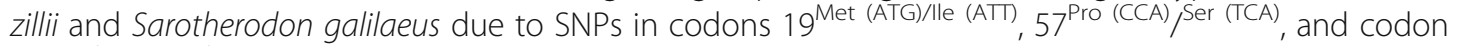
$14^{\text {Leu (CT / CTC) }}$. Hepcidins 1 and 2 coding region sequences in three tilapia species deposited to GeneBank and phylogenetic analysis indicated that tilapia species are more similar to each other and closely related to Sea perch. On the other hand, the expression levels of hepc1 and hepc2 genes were over-expressed in different tilapia tissue species (hepc1 in Sarotherodon galilaeus and hepc2 in Tilapia zillii).

Conclusions: The results concluded that the hepcidin 1 and 2 genes showed constitutive expressions in most of tested tissues and have a very similar three-dimensional structure as well as mature peptides which mean that these genes are highly conserved within the species examined.
\end{abstract}

Keywords: Tilapia, RT-PCR, Sequencing, Antimicrobial peptides, Hepcidin

\section{Introduction}

Fish have developed several defense mechanisms against waterborne pathogens with one of the first lines of defense consisting relatively small peptides called antimicrobial peptides (AMPs) (Neves et al. 2015). Antimicrobial peptides are identified as a positively charged molecules with short amino acid chains which play crucial roles in host defense against pathogens through antimicrobial actions or immunomodulatory functions (Jenssen et al. 2006). Among these peptides, a cystinerich molecule isolated from human urine named hepcidin (Hep) is based on its hepatic expression and antibacterial effect in vitro (Falzacappa and Muckenthaler

\footnotetext{
*Correspondence: I_fathy@yahoo.com

Cell Biology Department, National Research Centre, 33 El Buhouth St., postal code 12622, Dokki, Giza, Egypt
}

(c) The Author(s). 2020 Open Access This article is distributed under the terms of the Creative Commons Attribution 4.0 International License (http://creativecommons.org/licenses/by/4.0/), which permits unrestricted use, distribution, and reproduction in any medium, provided you give appropriate credit to the original author(s) and the source, provide a link to the Creative Commons license, and indicate if changes were made.
2005). Hepcidin has a dual function as a key regulator of iron metabolism and as a defense peptide (Ganz 2003). Fish hepcidin was first identified and isolated from the hybrid striped bass (Hirono et al. 2005), and since then, hepcidins have been identified in at least 37 fish species (Masso-Silva and Diamond 2014). In fish and mammals, hepcidin genes consist of three exons and two introns which encode a pre-pro peptide, an acidic propiece, and a mature peptide (Douglas et al. 2003). The pre-pro peptides contain a furin cleavage site, and the mature peptide contains eight conserved cysteines and a conserved glycine residue (Asmamaw 2016).

Fish hepcidin are highly expressed in the liver and kidney while they are less expressed in the heart, brain, skin, intestine, blood cells, spleen, and stomach and unnoticeable in muscle (Asmamaw 2016). Earlier studies

\section{Springer Open}


found that the expression of hepcidin is upregulated during infection, inflammation, and iron overload and predominantly reduced under certain conditions like anemia and hypoxia (Ganz 2007). The development of hepcidins are assorted in teleost fishes as it is influenced by the diversity of aquatic environments in which it is found (Lee et al. 2012). It has been found that the two hepcidin peptides identified in teleost fish show a degree of sub functionalization of its functions, where hepcidin 1 (HAMP1) more implicated in iron metabolism regulation and hepcidin 2 (HAMP2) mainly performing an antimicrobial role (Neves et al. 2015). The AMP production go through a main pathway by the recognition of pathogen-associated molecular patterns (PAMPs) through receptors (PRRs), such as Toll-like receptors (TLRs), exciting a cascade of intracellular signaling involving MyD88, TRAF6, IRAK1, and IKK that promotes the activation and translocation of NF-kB to the nucleus where it transcriptionally stimulates AMPs and other effector molecules (Campoverdea et al. 2017).

In fact, the structures and sequences of hepcidin genes are highly preserved between mammals and fish (Hsieh et al. 2010). According to previous studies on different fish species, two types of hepcidins have been identified in turbot (Scophthalmus maximus), using Matras with approximately $50 \%$ sequence identity; the synthesized form of these peptides showed apparent bactericidal activities against both Gram-positive and Gram-negative bacteria in a dose-dependent manner (Jain et al. 2015). Concerning the analysis results of genomic characterization and gene expression of four hepcidin genes in the red-banded seabream (Pagrus auriga), it was apparent that although hepcidin antimicrobial peptides (HAMP) might play an important role against bacterial infections, it also has additional functions in iron regulation and embryogenesis in fish (Martin-Antonio et al. 2009). Former study by Pridgeon (2012) demonstrated relative transcriptional levels of AMHP, using quantitative polymerase chain reaction (QPCR), in response to Edwardsiella ictaluri infection. After identification and characterization of AMHP in miiuy croaker, Xu et al. (2012) concluded that the expression level of these peptides was highest in the liver and an upregulation of transcription was seen in the intestine, spleen, and kidney in response to pathogenic bacteria, Vibrio anguillarum, which implied that HAMP has a vital role as a first line of defense against invading pathogens.

The objective of this study was to investigate the molecular characterization and expression analysis of hepc1 and hepc 2 in three strains of tilapia species infected naturally in Lake Manzala.

\section{Materials and methods}

One hundred and ten fishes were collected from Lake Manzala in Egypt.

\section{a. Collection of samples}

Tissue samples were obtained from normal and naturally infected fish in Lake Manzala. The selected tissues were gonads, spleen, head kidneys, and liver. The fish was kept on ice, while the tissues were kept in Hank's Balanced Salt Solution (HBSS), then they were homogenized and the PeqGold TriFast ${ }^{\mathrm{Tm}}$ (or Trisure or Tripure) (stabilization solution) was added. After this addition, the RNA was not degraded by Rnase and the samples could be stored at $-80{ }^{\circ} \mathrm{C}$ indefinitely. Individual fish were dissected, and these samples were collected for bacteriological examination, and isolation of some types of bacteria was attempted according to Noga (1996).

\section{b. RNA isolation and cDNA synthesis}

Total RNA was isolated from several tissues (gills, kidney, liver, and spleen) of Oreochromis niloticus, Sarotherodon galilaeus, and Tilapia zillii.Tissue samples were separately ground quickly in liquid nitrogen and transferred to $1 \mathrm{~mL}$ TRIzol solution (cat\#15596-026, Invitrogen, Germany) to isolate RNA following the manufacturer's instructions. RNA was quantified and checked for purity using a NanoDrop (Thermo Scientific, Waltham, MA, USA). Integrity was assured with ethidium bromide-stain analysis of $28 \mathrm{~S}$ and $18 \mathrm{~S}$ bands by formaldehyde-containing agarose gel electrophoresis. Extracted RNA was stored in a $-80^{\circ} \mathrm{C}$ freezer until used as template for reverse transcription PCR (RT-PCR). One microliter of RNA isolated from several tissues was reverse transcribed into cDNA in a total volume of $20 \mu \mathrm{l}$ using Revert AidTM First Strand cDNA Synthesis Kit (MBI Fermentas, Germany) according to the manufacturer's instructions.

\section{c. Primer design and PCR optimization}

The specific primers for the antimicrobial peptide genes were designed using known sequences of Teleost AMPs using the methodology of the homology cloning. Eleven pairs of primers were designed using the free primer3 online software (http://frodo.wi.mit.edu/primer3/), based on the NCBI reference sequences. Accession numbers of the genes for which the primers are designed are listed in Table 1 . They are aimed to amplify fish antimicrobial peptides messenger RNAs (mRNAs) using PCR. All the primers pairs were designed to amplify full coding sequence of the target antimicrobial peptide mRNA. The designed primers to amplify hepcidin mRNA in Oreochromis niloticus, Tilapia zillii, and Sarotherodon galilaeus based on the conserved region in hepcidin mRNA of bony fish. The primers were synthesized by HVD life sciences GMBH, Germany. Designed 
Table 1 The designed primer sequences used for PCR amplification and RT-PCR in tilapia species

\begin{tabular}{|c|c|c|c|}
\hline Gene name & Forward sequence & Sequence and RT-PCR & NCBI reference sequence \\
\hline Hepcidin 1 & $\begin{array}{l}\text { 5'-ACCAGGAGAAAGAGTCAAAC-3' } \\
\text { 5'-ACAGTATAATCTCACACATTGTC-3' }\end{array}$ & Sequence & XM_003456839.1 \\
\hline Hepcidin 2 & $\begin{array}{l}\text { 5'-TCTTCAAAGGGTACAACAAC-3' } \\
\text { 5'-AGAAAGAGTCAGACAATAAGC-3' }\end{array}$ & Sequence & XM_003450530.4 \\
\hline Hepcidin 1 & $\begin{array}{l}\text { 5'-CAG CAG CAC ATG AGG AGG CAT-3' } \\
\text { 5'-ACC TGC AGC AAA CTC CAC AGA-3' }\end{array}$ & RT-PCR & MH651353.1 \\
\hline Hepcidin 2 & $\begin{array}{l}\text { 5'-AGA GCA ATG ACA CTC CAG TTG-3' } \\
\text { 5'-AGA TGG CTC TGA CGC TाT TG-3' }\end{array}$ & RT-PCR & MH651359.1 \\
\hline$\beta$-Actin & $\begin{array}{l}5^{\prime}-\mathrm{CGG} \text { AAT CCA CGA AAC CAC CTA-3' } \\
5^{\prime}-T T G \text { CTG ATC CAC ATC TGC TGG-3' }\end{array}$ & RT-PCR & AB037865.1 \\
\hline
\end{tabular}

primers were tested in order to determine its optimum annealing temperature that amplifies the target cDNA segment.

\section{d. Polymerase chain reaction (PCR) amplification}

PCR amplification of cDNA was performed according to the method described by Ausubel et al. (1990). The optimized PCR cycles were differed according to the gene under study. The PCR cycle started with initial denaturation of $94{ }^{\circ} \mathrm{C}$ for $5 \mathrm{~min}$, then followed by 35 cycles (three steps) as: $94{ }^{\circ} \mathrm{C}$ for $30 \mathrm{~s}$, annealing temperature for $45 \mathrm{~s}$. with variable temperatures according to the gene under study, then extension at $72{ }^{\circ} \mathrm{C}$ for $1 \mathrm{~min}$ and finally one step for final extension $72^{\circ} \mathrm{C}$ for $5 \mathrm{~min}$. The annealing temperatures were as follows: hepcidin 1 $\left(53^{\circ} \mathrm{C}\right)$ and hepcidin $2\left(55^{\circ} \mathrm{C}\right)$. For the PCR optimization and detection of the PCR success, some of the PCR products were subject to run horizontally on agarose electrophoresis and stained with ethidium bromide.

e. Sequencing, alignment analysis and amino acid translation

Prior to sending the PCR products to the company for sequencing, the PCR products were purified using GeneJET Gel Extraction Kit from Thermo scientific Company according to the manufacturer's instructions. PCR products from two genes (hepcidin 1 and hepcidin 2) of three tilapia fish species were sent for sequencing in Macrogen Company (South Korea).

\section{Statistical analysis}

Sequence analysis was performed by multiple alignments using CLUSTAL-W program (Thompson et al. 1994). Protein translations of CDs sequences were carried out using open reading frame finder (https://www.ncbi.nlm. nih.gov/orffinder/) while modeling of hepcidin protein was determined by Phyre2 software (http://www.sbg.bio. ic.ac.uk/phyre2/). For the analysis of potential cleavage site of the signal peptide, SignalP Software was used
(http://www.cbs.dtu.dk/services/SignalP/). The alignment of the amino acid sequences of hepcidin proteins was done using Clustal X. The phylogenetic tree was drawn by the neighbor-joining method (Saitou and Nei 1987) and analyzed with MEGA-3 (Kumar et al. 2018).

\section{Quantitative evaluation of hepcidin 1 and 2 mRNA by real-time PCR (qPCR)}

StepOne $^{\mathrm{TM}}$ Real-Time PCR System from Applied Biosystems (Thermo Fisher Scientific, Waltham, MA USA) was used to determine the tilapia's cDNA copy number. Sequencing results of different hepcidin genes were used to design gene specific primers, for $\mathrm{qPCR}$, by using the Primer3 program (http://frodo.wi.mit.edu/cgi-bin/primer3/ primer3_www.cgi). $\beta$-Actin gene used as internal control to correct for differences in total cDNA input between samples. PCR reactions were set up in $25 \mu \mathrm{L}$ reaction mixtures containing $12.5 \mu \mathrm{L} \times 1 \mathrm{SYBR}^{\odot}$ Premix Ex TaqTM (TaKaRa, Biotech. Co. Ltd.), $0.5 \mu \mathrm{L} 0.2 \mu \mathrm{M}$ sense primer, $0.5 \mu \mathrm{L} 0.2 \mu \mathrm{M}$ antisense primer, $6.5 \mu \mathrm{L}$ distilled water, and $5 \mu \mathrm{L}$ of cDNA template. The qPCR conditions were $95.0^{\circ} \mathrm{C}$ for $10 \mathrm{~min}$ followed by 40 cycles of $95.0^{\circ} \mathrm{C}$ for $15 \mathrm{~s}$ and $60.0 \mathrm{C}$ for $1 \mathrm{~min}$. The relative amount of the genes of interest was calculated by the comparative threshold cycle (CT) method with efficiency correction, using the mean PCR efficiency for each amplicon (Ruijter et al. 2009). The sequences of QPCR primers are listed in Table 1.

\section{Results}

\section{Naturally infected tilapia}

Three strains of fish including O. niloticus, T. zillii, and S. galilaeus were naturally infected with bacteria in the Lake Manzala. The O. niloticus strain was infected with Aeromonas hydrophila but T. zillii and S. galilaeus were infected by Pseudomonas luteola.

\section{Polymerase chain reaction (PCR)}

Hepcidin 1 gene-specific primers amplified a product of $264 \mathrm{bp}$ and hepcidin 2 gene-specific primers amplified a product of $273 \mathrm{bp}$ (Fig. 1). 


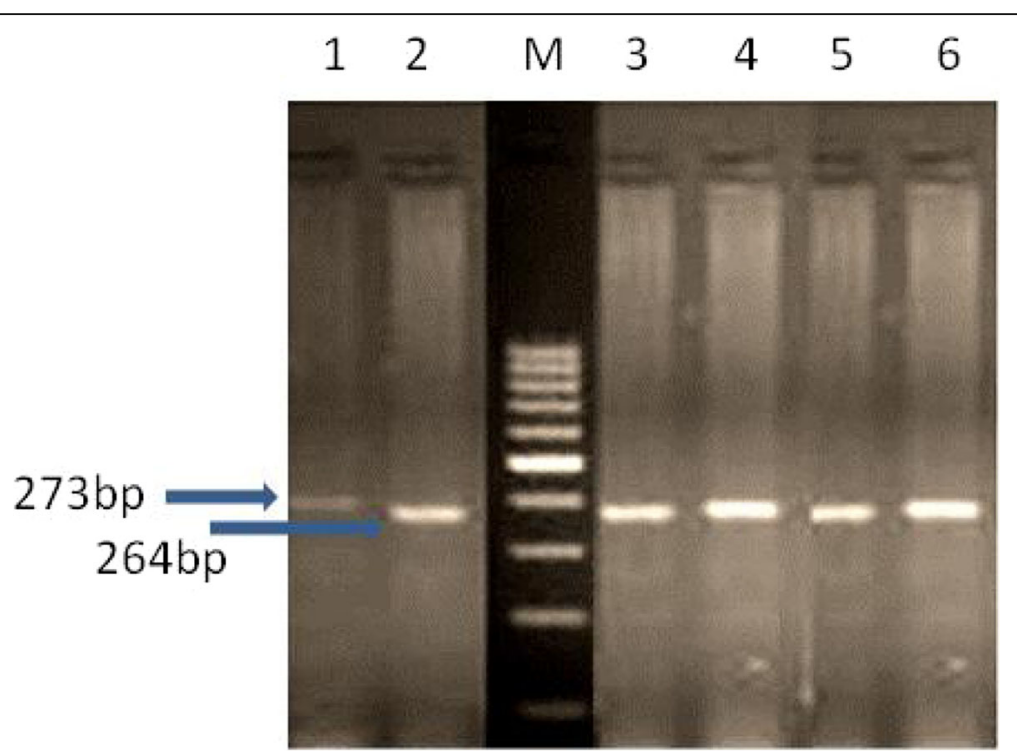

Fig. 1 Agarose gel electrophoresis of hepcidin1 (264 bp) and hepcidin 2 (273 bp)-PCR fragment. M, 100 bp DNA ladder, Lanes 1, 4, and 6 (hepcidin 2). Lanes 2, 3, and 5 (hepcidin1)

Characterization of hepcidin 1 coding region sequences in O. niloticus, T. zillii, and S. galilaeus

The O. niloticus, T. zillii, and S. galilaeus hepcidin 1 coding region (CDs) were sequenced, and their sequences have been deposited to GeneBank with accession numbers of (MH651353, MH651354, and MH651358), respectively. CD regions of T. zillii and $S$. galilaeus have the same length $(264 \mathrm{bp})$ while $O$. niloticus has 258-bp CD length with a deletion portion (AGCAGG) when aligned with T. zillii and S. galilaeus CDs (Fig. 2). Moreover, two SNPs are determined among these species at nt $36(\mathrm{C} / \mathrm{G})$ and at nt $240(\mathrm{~A} / \mathrm{C})$.
Four genotypes are determined in $S$. galilaeus species due to the presence of SNPs at nt $101 \mathrm{~W}(\mathrm{~A} / \mathrm{T})$ and $n t$ $108 \mathrm{R}$ (G/A) while no different genotypes are detected in O. niloticus and T. zillii species (Fig. 2).

The deduced amino acid sequences for hepcidin 1 CDs of T. zillii and S. galilaeus consists of 87 amino acids. One SNP at nt 101 which presents in codon 34 (CAG/CTG) in $S$. galilaeus species is translated glutamine $(\mathrm{Q})$ into leucine $(\mathrm{L})$ while the other SNP at nt 108 which correspond to codon 36 (GAA/GAG) is silent mutation as in Fig. 2a, b. On the other hand, the amino acid sequence for hepcidin $1 \mathrm{CD}$ of $O$. niloticus species

\begin{tabular}{|c|c|c|}
\hline o. niloticus & ATGAAGACGITCAGPGTTGCAGTTGCAGTGGCCGTCGTGCTCACATTCATCTGIGTTCAG & 60 \\
\hline T. zillii & ATGAAGACGITCAGPGITGCAGTIGCAGTGGCCGPGGIGCTCACATTCATCTGIGTICAG & 60 \\
\hline S.galilaeus & ATGAAGACGITCAGTGITGCAGTTGCAGTGGCCGICGIGCTCACATTCATCTGIGTTCAG & 50 \\
\hline o.niloticus & CAGAGCTCTGCTGTCCCAGTCACTGAACAGG------AGCTGGAGGAGCCAATGAGCATG & 120 \\
\hline T.zil1ii & CAGAGCTCTGCTGTCCCAGTCACTGAACAGGAGCAGGAGCIGGAGGAGCCAATGAGCATG & 120 \\
\hline S.galilaeus & CAGAGCTCTGCTGTCCCAGTCACTGAACAGGAGCAGGAGCAGGAGGARCCAATGAGCATG & 120 \\
\hline o.niloticus & GACTATCCAGCAGCAGCACATGAGGAGGCATCAGTGGACTCATGGAAGATGCTGIATAAC & 180 \\
\hline T. zillii & GACTATCCAGCAGCAGCACATGAGGAGGCATCAGIGGACTCATGGAAGATGCTGIATAAC & 180 \\
\hline S.galilaeus & GACTATCCAGCAGCAGCACATGAGGAGGCATCAGIGGACTCATGGAAGATGCTGIATAAC & 180 \\
\hline o.niloticus & AGCAGACACAAGCGTGGCATCAAGTGTCGCTTTIGCTGIGGCTGCTGCACCCCCGGIATC & 240 \\
\hline T.zillii & AGCAGACACAAGCGTGGCATCAAGTGTCGCTITIGCTGIGGCTGCTGCACCCCCGGIATC & 24 \\
\hline S.galilaeus & AGCAGACACAAGCGPGGCATCAAGTGTCGCTITTGCTGTGGCTGCTGCACCCCCGGTATC & 24 \\
\hline 0.niloticus & TGTGGÄTTTGCTGCAGGTTCTGA & \\
\hline T. zillii & TGTGGCGTTTGCTGCAGGTTCTGA & \\
\hline S. galilaeus & TGTGGAGTTTGCTGCAGGTTCTGA & \\
\hline
\end{tabular}

Fig. 2 Alignment of CD regions of O. niloticus, T. zillii, and S. galilaeus species shows two SNPs at nt 36 (C/G) and at nt 240 (A/C) in red box and deletion portion of $O$. niloticus species in bold and underlined while different genotypes of S. galilaeus species in blue box 


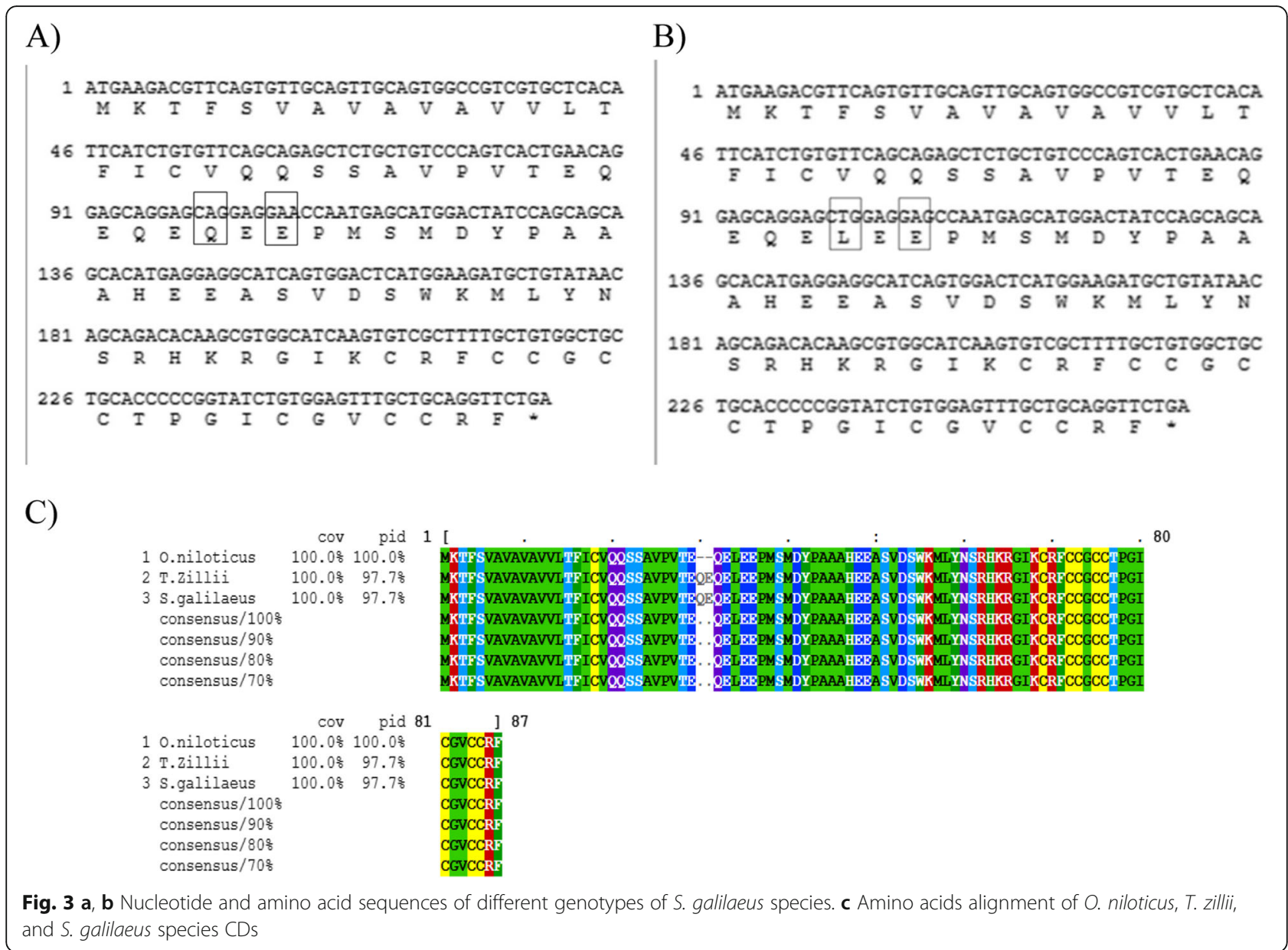

is 85 amino acids due to deletion portion which detected in nucleotide sequence as shown in Fig. 3 a, b and c.

\section{Sequence alignment and phylogenetic analysis}

The deduced amino acid sequences of hepcidin 1 in $O$. niloticus, T. zillii, and S.galilaeus have been aligned with protein sequences of turbot_S.maximus (AY994074), Homo sapiens (BC020612), white bass (AAM28440), Atlantic salmon (BI468191), Canis lupus familiaris (AY899807), mus musculus (BC021587), black seabream (AAU00801), red seabream (AAR28076), Pig (NP_ 999282), sea perch (AAT09138), Japanese flounder (BAE06234), winter flounder (AW013026), channel catfish (AAX39713), blue catfish (AAX39714), and zebrafish (P61516) as in Fig. 4. It is obvious that O. niloticus, T. zillii, and S. galilaeus hepcidin 1 gene is more similar to each other and closely related to sea perch than other species (Figs. 4 and 5).

\section{Characterization of hepcidin 2 coding region sequences in O. niloticus, T. zillii, and S. galilaeus}

The O. niloticus, T. zillii, and S. galilaeus hepcidin 2 CDs were sequenced, and their sequences have been deposited to GeneBank with accession numbers of (MH651359.1, MH651363.1, and MH651367.1), respectively. CD regions in these species have the same length (273 bp) with identical sequence except in two SNPs at positions nt $252(\mathrm{~T} / \mathrm{C})$ and nt 310 (G/A). Four genotypes are determined in $T$. zillii due to the presence of SNPs at nt $101 \mathrm{~K}(\mathrm{G} / \mathrm{T})$ and nt $213 \mathrm{Y}(\mathrm{C} / \mathrm{T})$. In addition, four genotypes are detected in $S$. galilaeus due to the presence of SNPs at nt $86 \mathrm{Y}(\mathrm{C} / \mathrm{T})$ and nt $101 \mathrm{~K}(\mathrm{G} / \mathrm{T})$ while no different genotypes are detected in $O$. niloticus (Fig. 6).

The deduced amino acid sequence for hepcidin 2 gene of O. niloticus, T. zillii, and S. galilaeus consists of 90 amino acids. The two SNPs at nt 101 and nt 213 are present in codons 19 (ATG/ATT) and 57 (CCA/TCA) in T. zillii species are translated methionine (M) into isoleucine (I) and proline (P) into Serine (S) as shown in Fig. 7a, b. On the other hand, S. galilaeus species has SNP at nt 101 which present in codon 19 (ATG/ATT) is translated into methionine (M) into isoleucine while, the other SNP at nt 86 which correspond to codon 14 (CTT/CTC) is a silent mutation as in Fig. 7c, d. In addition, the only 


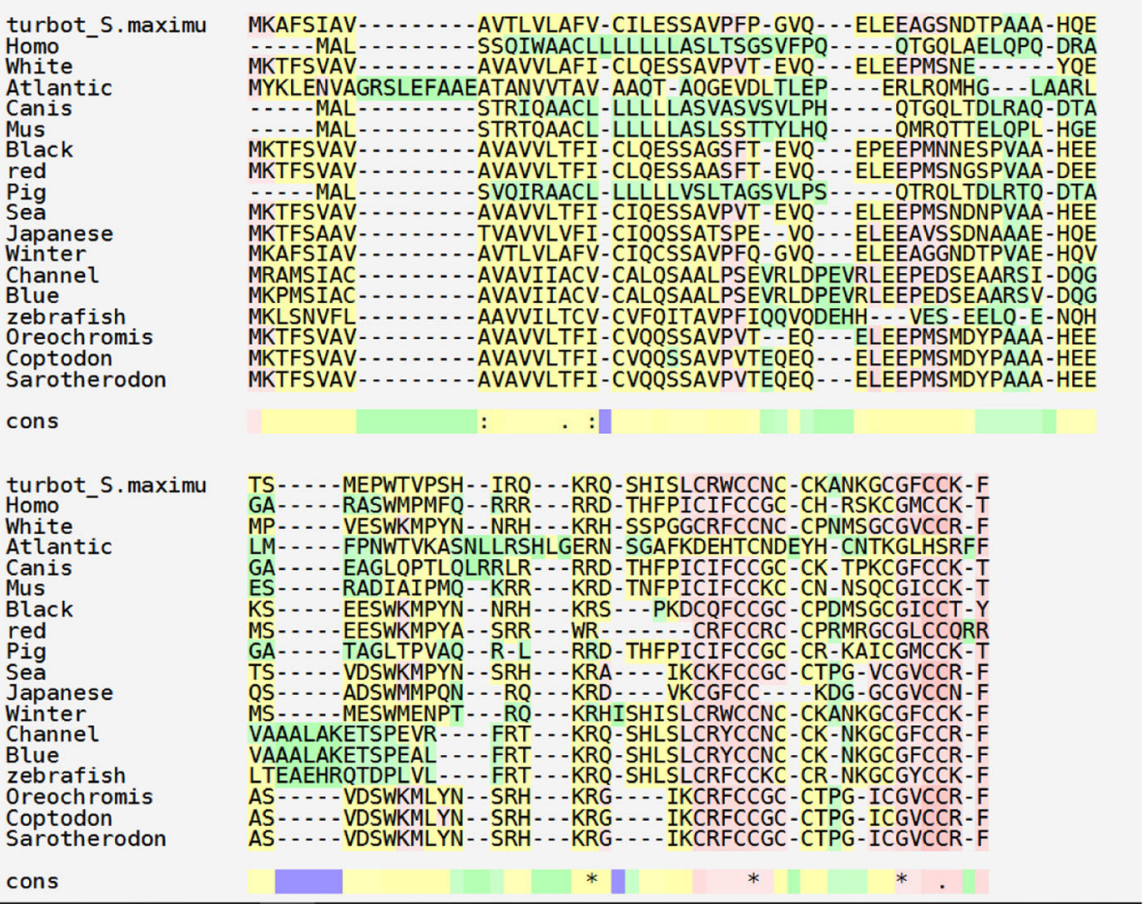

Fig. 4 Alignment of deduced amino acid sequences of O. niloticus, T. zillii, and S. galilaeus hepcidin 1 gene with those of turbot_S.maximus (AY994074), Homo sapiens (BC020612), white bass (AAM28440), Atlantic salmon (BI468191), Canis lupus familiaris (AY899807), Mus musculus (BC021587), black seabream (AAU00801), red seabream (AAR28076), pig (NP_999282), sea perch (AAT09138), Japanese flounder (BAE06234), winter flounder (AW013026), channel catfish (AAX39713), blue catfish (AAX39714), and zebrafish (P61516)

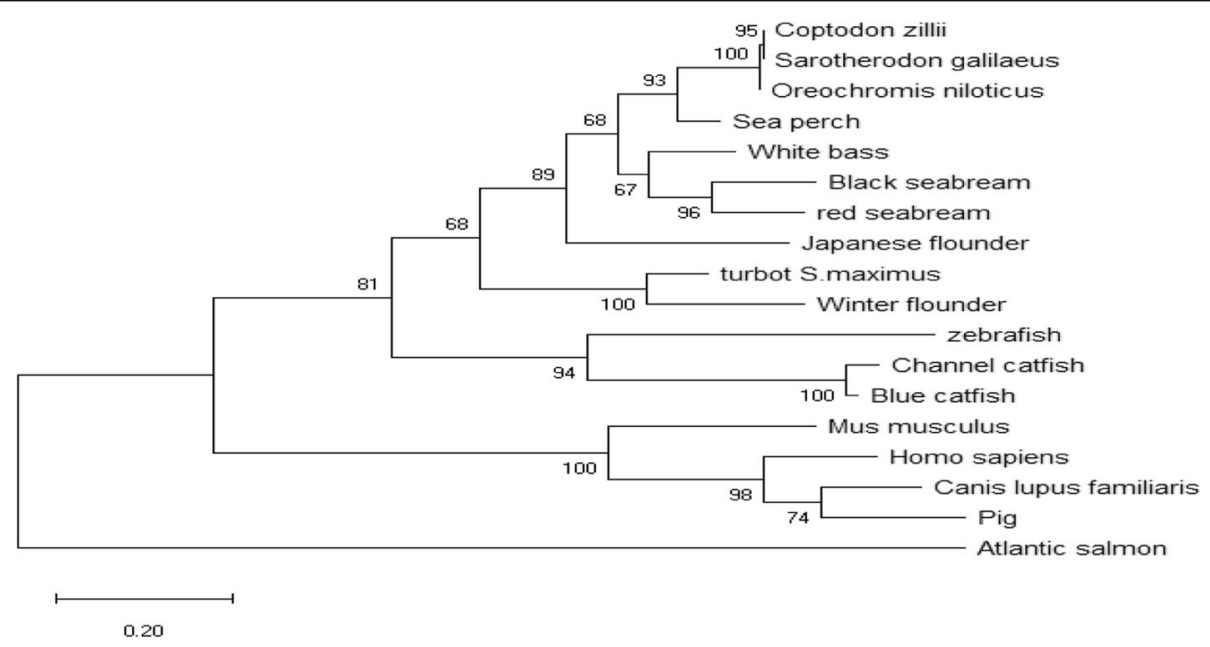

Fig. 5 Phylogenetic analysis of O. niloticus, T. zillii, and S. galilaeus hepcidin 1 gene and other species. Constructions are formed on the basis of the homology sequences calculated from the complete amino acid sequence of hepcidin genes. The tree is constructed using a neighbor-joining method. The scale is 0.20 which refers to percentage of divergence 


\begin{tabular}{|c|c|c|}
\hline O.niloticus & TCTTCAAAGGGTACAACAACTTAACCATTTAAACCCCGACCAAAATGAAGGCATTCAGCA & 60 \\
\hline $\begin{array}{l}\text { S-galilaeus } \\
\text { T-zillii }\end{array}$ & 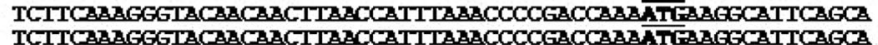 & $\begin{array}{l}60 \\
60\end{array}$ \\
\hline O.niloticus & TTGCAGTTGCAGTEACACTCGTGCICGCCTITATTTGCATGKTGGAGAGCTCTGCCATCX & 120 \\
\hline $\begin{array}{l}\text { S-galilae } \\
\text { T.zillii }\end{array}$ & $\begin{array}{l}\text { TTGCAGTTGCAGTGACACTCGTGCIYGCCTITATTTGCAIKKTGGAGAGCTCTGCCATCD } \\
\text { TTGCAGITGCAGTEACACTCGTGCICGCCTTTATTTGCATKCTGGAGAGCTCTGCCATCX }\end{array}$ & $\begin{array}{l}120 \\
120\end{array}$ \\
\hline O.niloticus & СATTTG:TGGGGTGCAAGAGCCGGAGGAGGCAGGGAGCAATEACACTCCAGTTGTGGCAC & 180 \\
\hline S-galilaeug & CATTTGTTGGGGTGCAAGAGCCGGAGGAGGCAGGGAGCAATEACACTCCAGTTGTGGCAC & 180 \\
\hline T.zillii & CATTTECTGGGGTGCAAGAGCCGGAGGAGGCAGGGAGCAATEACACTCCAGITGTGGCAC & 180 \\
\hline O.niloticus & ATCAAEAGATGTCAGCGGAGTCATCAATGATGTCAAATCACATCAGGCAAAAGCGTCAGA & 240 \\
\hline S.galilaeug & ATCAAGAGATGTCAGCGGAGTCATCAATGATETCAAATCACATCAGGCAAAAGCGTCAGA & 240 \\
\hline T.zillii & ATCAAGAGATGTCAGCGGAGTCATCAATGATGYCAAATCACATCAGGCAAAAGCGTCAGA & $\mathbf{2 4 0}$ \\
\hline O.niloticug & GCCATCTITCCITENGCCGCTGGIGCTGCAATTGCTECCGAAGCAACAAEGGCTGCGGCT & 300 \\
\hline S-galilaeug & GCCATCITTCCITGIGCCGCTGGIGCTGCAATTGCTGCCGAAGCAACAAGGGCTGCGGCI & $\mathbf{3 0 0}$ \\
\hline T_zillii & GCCATCTITCCCTGIGCCGCTGGIECTGCAATTGCTGCCGAAGCAACAAGGGCTGCGGCT & 300 \\
\hline O.nilotic & TCTGCFECAGGITCTEAGGATTCOCGCAACAGCOACAAAATATTAATTTATTATGCTTAT & 360 \\
\hline S.galilaeug & TCTGCHGCAGGTTCFEAGEATTCOCGCAACAGCOACAAAATATTAATTTATTATGCTTAT & 360 \\
\hline T_zillii & TCTGCTGCAAGTTCTFAGATTCCOGCAACAGCOACAAAATATTAATTTATTATGCTTAT & 360 \\
\hline o.nilot & TGTCTGACTCTTTCT & \\
\hline alile & TGTCTGACTCTTTCT & \\
\hline T_zillii & TGTCTGACTCTTTCT & \\
\hline
\end{tabular}

Fig. 6 CDNA sequence of hepcidin 2 gene. The coding regions start codon ATG and termination codon TGA are both bold and underlined. The alignment of nucleotide sequences of O. niloticus, T. zillii, and S. galilaeus shows two SNPs at nt 252 (T/C) and nt 310 (G/A) (in red box) and different genotypes for each species (in blue box)

genotype detected for $O$. niloticus has methionine $(\mathrm{M})$ at codon 19 (ATG) as in Fig. 7e.

\section{Sequence alignment and phylogenetic analysis}

The deduced amino acid sequences of hepcidin 2 in O. niloticus, T. zillii, and S. galilaeus have been aligned with protein sequences of turbot_S.maximus (AY994074), Homo sapiens (BC0 C0 20612), white bass (AAM28440), Atlantic salmon (BI468191), Canis lupus familiaris (AY 89980897), Mus musculus (BC021587), black seabream (AAU00801), red seabream (AAR28076), pig ( $\mathrm{N}_{-} \mathrm{P}_{-}$999282), sea perch (AAT09138), Japanese flounder (BAE06234), winter flounder (AW W1013026), channel catfish (AAX39713), Blue catfish (AAX39714), zebrafish (P61516) as in Fig. 8. It is obvious that O. niloticus, T. zillii, and S. galilaeus hepcidin 2 gene is more similar to each other and closely related to sea perch than other species (Fig. 9).

Structural model analysis of hepcidin 1 and hepcidin 2 and signal peptide detection

Three-dimensional structure of hepcidin 1 and hepcidin 2 shows it to be an amphipathic molecule composed of two distorted antiparallel $\beta$-sheets separated by a hairpin loop, containing a vicinal disulfide bond (disulfide bond between adjacent cysteines), and stabilized by three inter- $\beta$-sheet disulfide bonds which remarkably similar among O. niloticus, T. zillii, and S. galilaeus species as shown in Fig. 10a and b. On the other hand, the signal peptide is detected from 1 to 24 amino acids with high probability ( 0.9753 and 0.9968 , respectively) and mature protein starts at position 25 amino acid (Fig. 11a, b).

Gene expression results

Expression of antimicrobial peptide gene hepcidin 1 (H1) in $O$. niloticus, T. zillii, and S. galilaeus naturally infected with bacteria in the Lake Manzala

The expression levels of the antimicrobial peptide gene hepcidin 1 (H1) in several tissues of O. niloticus, T. zillii, and S. galilaeus were quantified by real-time RT-PCR (Fig. 12). The results revealed that expression levels of h1 gene were increased in tissues of $S$. galilaeus compared with those of $O$. niloticus and $T$. zillii. Moreover, the lowest expression levels of h1 gene were observed in tissues of the T. zillii. Additionally, the highest expression levels were observed in the gills and spleen tissues of all fish strains compared with kidney and liver tissues.

Expression of antimicrobial peptide gene hepcidin 2 (H2) in O. niloticus, T. zillii, and S. galilaeus naturally infected with bacteria in the Lake Manzala

The expression levels of the antimicrobial peptide gene hepcidin $2(\mathrm{H} 2)$ in several tissues of $O$. niloticus, T. zillii, and $S$. galilaeus were quantified by real-time RT-PCR 


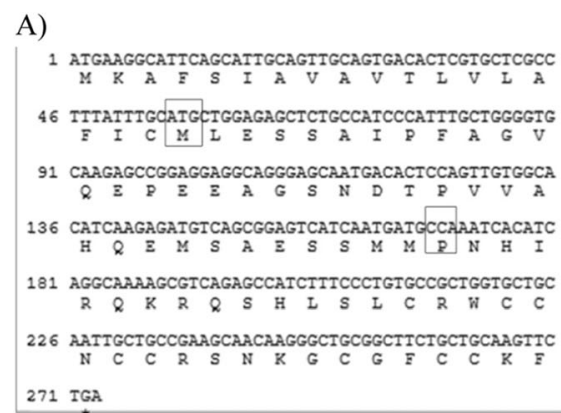

C)

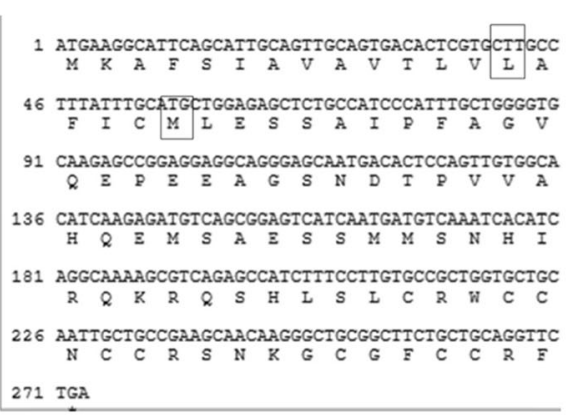

B)

1 ATGAAGGCATTCAGCATTGCAGTIGCAGTGACACTCGIGCTCGC

46 ITIATTTGCATACTGGAGAGCTCTGCCATCCCATTTGCTGGGGTS F I C C I

91 CAAGAGCCGGAGGAGGCAGGGAGCAATGACACTCCAGTIGTGGCA

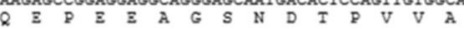

136 CATCAagagatgTCAgCGGAGTCATCAATGATGICAAATCACATC Q $E$ M S A E S S M M S N H I

181 AGGCAAAAGCGTCAGAGCCATCTITCCCTGTGCCGCTGGTGCTGC
$R$ \& $R$ \& $Q S$ H L S L C R W C C

226 AATTGCTGCCGAAGCAACAAGGGCTGCGGCTTCTGCTGCAAGTTC
N C C R S N K G C G $\bar{F} C \mathrm{C}$ K $\bar{F}$ 271 TGA

D)

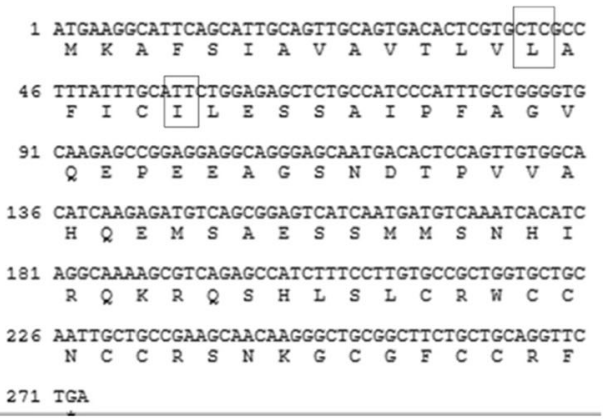
271 IGA

E)

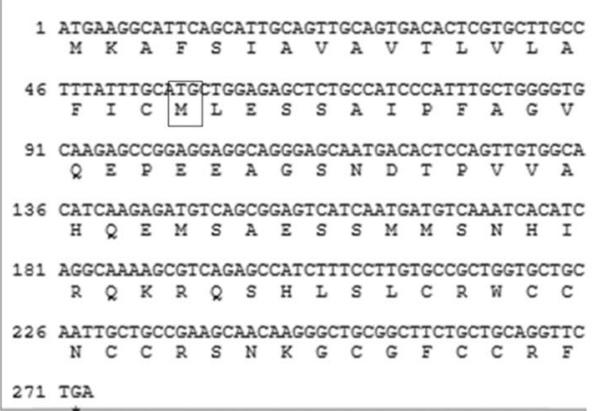

Fig. 7 a, b Nucleotide and amino acid sequences of different genotypes of T. zillii species. $\mathbf{c}$, $\mathbf{d}$ Nucleotide and amino acid sequences of different genotypes of S. galilaeus species. e Nucleotide and amino acid sequence of O. niloticus genotype

(Fig. 13). The results revealed that expression levels of $\mathrm{H} 2$ gene were increased in tissues of T. zillii compared with those of O. niloticus and S. galilaeus. Moreover, the lowest expression levels of $\mathrm{H} 2$ gene were observed in tissues of the $O$. niloticus. Furthermore, the highest expression levels were observed in the kidney and liver tissues of all fish strains compared with gills and spleen tissues.

\section{Discussion}

Fish is protecting their biological systems and fighting toward many of pathogens by producing a several types of AMPs (Rajanbabu and Chen 2011). In our knowledge, there are no published data concerning AMPs in S. galilaeus and T. zillii. The results of the present study found that sequence alignment for hepcidin 1 and 2 CDs of $S$. galilaeus and T. zillii have the same length; the sequence identity is $99.24 \%$ while the CD identity between $S$. galilaeus and O. niloticus is $100 \%$. The results showed that S. galilaeus possessed four genotypes in hepcidin 1 due to SNPs in codon $34^{\mathrm{Gln}}$ (CAG)/Leu (CTG) and codon $36^{\text {Glu (GAA/GAG) }}$ (silent mutation) and different genotypes in hepcidin 2 due to SNPs in codon $19^{\mathrm{Met} \text { (ATG)/Ile (ATT) }}$ and codon $14^{\mathrm{Leu}}$ (CTT/CTC) (silent mutation). On the other hand, different genotypes recorded in hepcidin 2 gene of T. zillii due to SNPs in codons $19^{\operatorname{Met}(\mathrm{ATG}) / \mathrm{Ile} \text { (ATT) }}$ and $57^{\text {Pro }(\mathrm{CCA}) / \mathrm{Ser} \text { (TCA) }}$ Previous studies stated that two forms of hepcidins were identified in turbot (Scophthalmus maximus) with $50 \%$ identity of sequencing (Zhang et al. 2014). In Miiuy croaker, two hepc 1 and 2 genes were identified with sequence similarity $99.6 \%$ (Xu et al. 2012). The sequence alignment of putative hepcidin genes in Nile and blue tilapia fishes, hepcidin 1 and hepcidin 2 

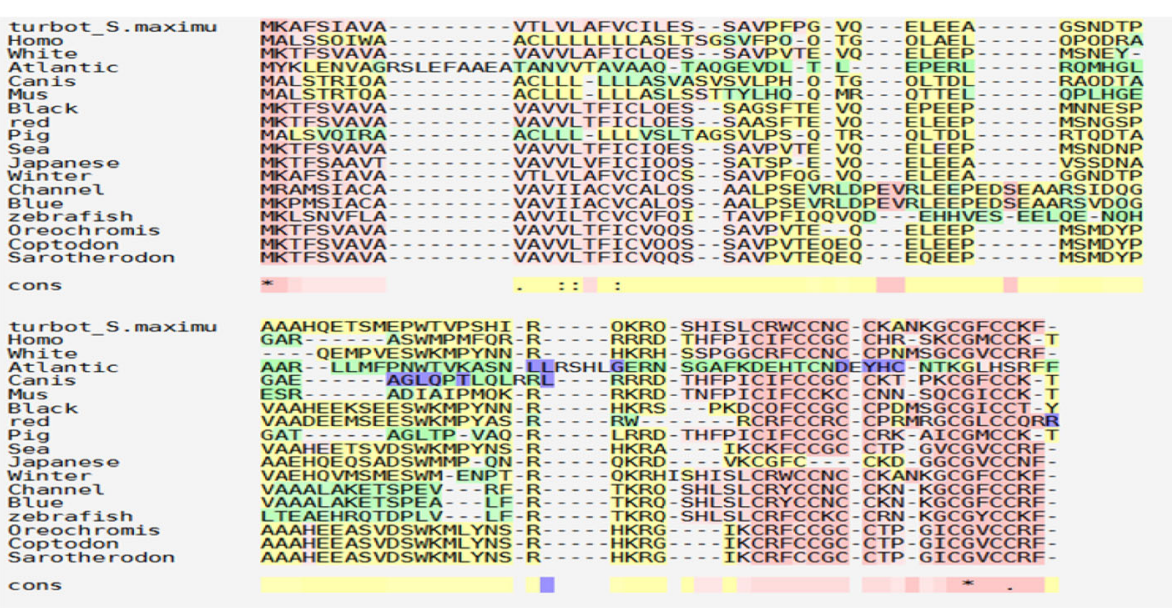

Fig. 8 Alignment of deduced amino acid sequences of O. niloticus, T. zillii, and S. galilaeus hepcidin 2 gene with those of turbot_S.maximus (AY994074), Homo sapiens (BC020612), white bass (AAM28440), Atlantic salmon (Bl468191), Canis lupus familiaris (AY899807), mus musculus (BC021587), black seabream (AAU00801), red seabream (AAR28076), pig (NP_999282), sea perch (AAT09138), Japanese flounder (BAE06234), winter flounder (AW013026), channel catfish(AAX39713), blue catfish (AAX39714), and zebrafish (P61516)

represented identity $>50 \%$ and $>80 \%$ (Bian et al. 2019). Parallel to our results, a study by Bao et al. (2006) reported that the sequence alignment of channel and blue catfish hepc 2 differ in two amino acids at two positions: (a) at 28 , the channel catfish hepc2 has a proline residue while the blue catfish hepc 2 has a serine residue, (b) at 32 , the channel catfish hepc2 has an arginine residue while the Blue catfish hepc2 has a proline residue. The two hepc 2 cDNAs of channel and blue catfish had 25 single-nucleotide polymorphisms. So far, Neves et al. (2015) detected high number of SNPs in the sequence of mature peptide ( 7 SNPs) compared with the remainder of prepropeptide (only $1 \mathrm{SNP}$ ) of hamp2 gene in sea bass. Furthermore, alignment of the two types of hepcidin in sea bass exhibited differences in the amino acids between both gene sequences of Hamp1 and Hamp2. However, the sequence of the mature peptides exhibited unchanged eight cysteine residues sequences at the conserved positions.

The action mechanism of how sequence differences in the SNPs formation is that it could be possible during life generation of the fish, various type of deletion or insertion might be occurred in the introns of the hepcidin

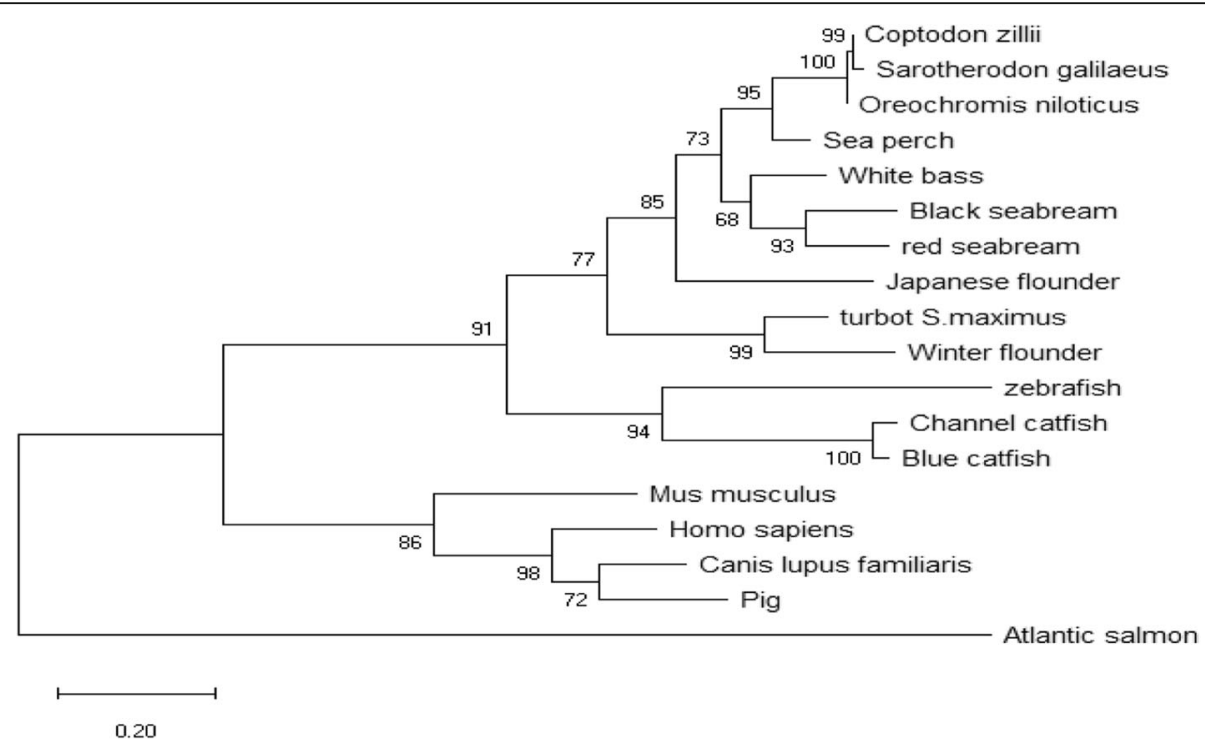

Fig. 9 Phylogenetic analysis of O. niloticus, T. zillii, S. galilaeus hepcidin 2 gene and other species. Constructions are formed on the basis of the homology sequences calculated from the complete amino acid sequence of hepcidin genes. The tree is constructed using a neighbor-joining method. The scale is 0.20 which refers to percentage of divergence 


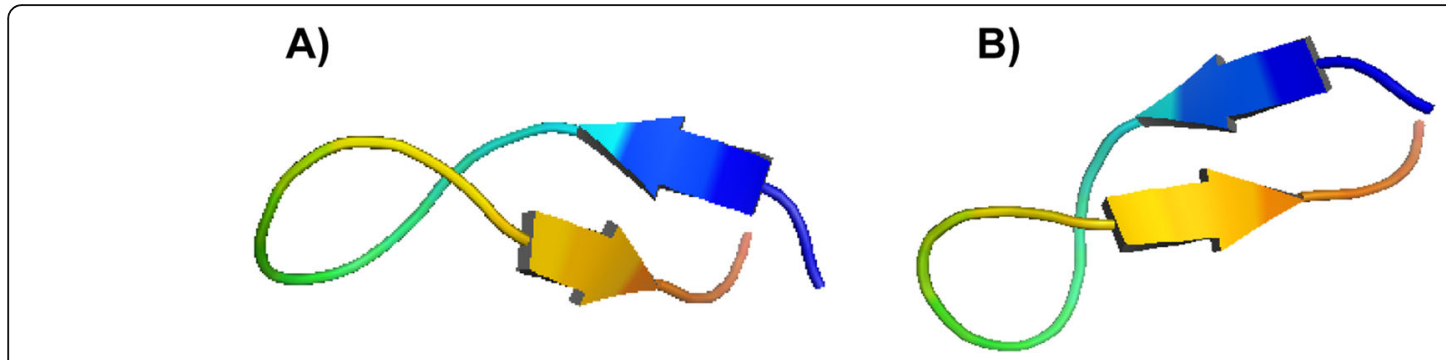

Fig. 10 a, b Three-dimensional structure of hepcidin 1 (a) and hepcidin 2 (b) in O. niloticus, T. zillii, and S. galilaeus species

sequences. However, molecular analysis in fish exhibited that a slight differences are occurred because the sequences of hamp1 and hamp2 genes are remain conserved.

The deduced amino acid sequences for hepcidin 1 CDs of T. zillii and S. galilaeus consists of 87 amino acids for $O$. niloticus 85 aa due to deletion portion in mature peptide while those for hepcidin 2 CDs encodes a peptide of 90aa in three tilapia species. Previous work by Bao et al. (2006) reported that hepcidin 2 of the blue catfish and channel catfish shared similar features as it encodes a peptide of 94 aa. The results of numerous studies conducted by Wang et al. (2012), Hu et al. (2007), and Shi and Camus (2005) showed that a hepcidin of 78 aa and 96aa were detected in Tor putitora, Ictalurus punctatus, Cynoglossus semilaevis, respectively. As well as, results by Neves et al. (2015) detected that hepc1 and hepc 2 genes of teleost fish encode 91aa and $85 \mathrm{aa}$, respectively. The miiuy croaker HAMP was predicted to encode of 89 amino acids (Xu et al. 2012) which in consistent with results of Silva et al. (2011), where A. immaculatus prepro hepcidin is composed of 90 aa. It was concluded that the conserved functions of fish hepcidin is due to the conservation of their mature peptide.

Phylogenetic analysis indicated that translated protein of hepcidins CDs of the species examined are organized as clusters and very related to sea perch while so far from two or more hepcidins of winter flounder, Atlantic salmon, and mouse. Lauth et al. (2005) had shown that fish hepcidins in bass and tilapia species were characterized by cysteine-rich peptides and a central model of four conserved disulfide bridges. In addition, a study by Huang et al. (2007) revealed that tilapia hepcidin (2-3) situated in a group with Japanese flounder hepcidin-JF1, 2 and tilapia hepcidin $2-2$ while tilapia hepcidin $1-5$ is closest to white bass and black porgy which suggest that the three tilapia hepcidins may have different functions. Based on results recorded by Silva et al. (2011), HAMP1of A. Immaculatus had a sequence similarity of $96 \%$ with Serranid fish and Epinephelus moara and grouped with A. immaculatus in the same cluster. According to
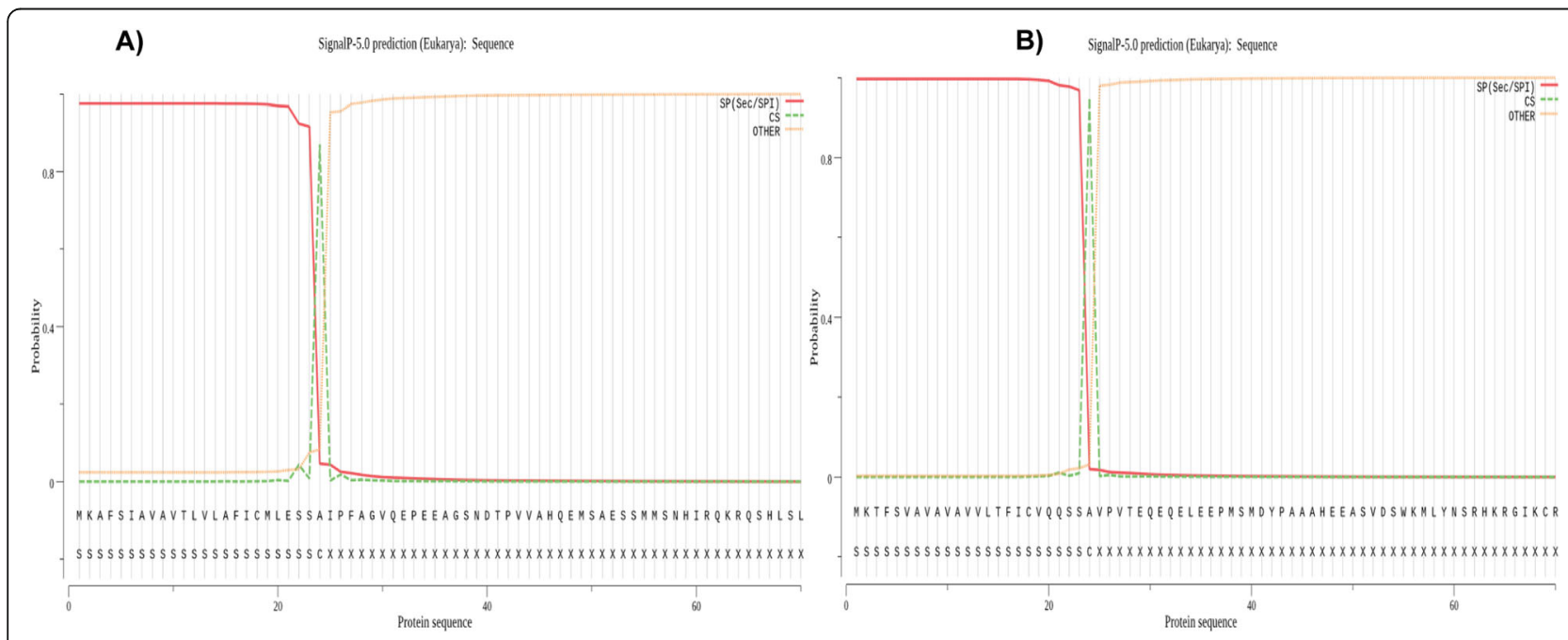

Fig. 11 a, b Signal peptide analysis of O. niloticus, T. zillii, and S. galilaeus species hepcidin 1 (b) and hepcidin 2 (a) gene indicated to the cleavage site is predicted between amino acids 24 and 25 with probability (0.9753 and 0.9968 , respectively) 


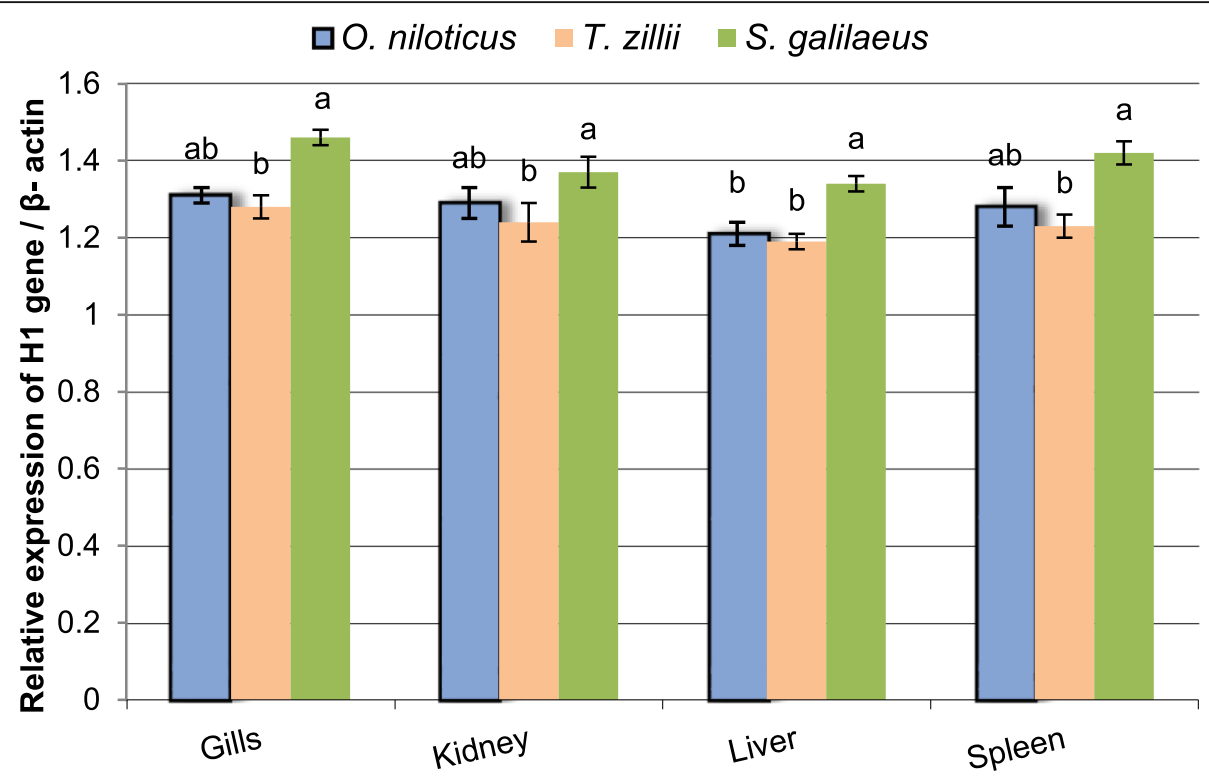

Fig. 12 Expression levels of some antimicrobial peptide gene hepcidin $1(\mathrm{H} 1)$ in different tissues of O. niloticus, T. zillii, and S. galilaeus. Data are presented as mean \pm SEM. ${ }^{\text {a,b }}$ followed by different superscripts are significantly different $(P \leq 0.05)$

results reported by Neves et al. (2015), phylogenetic analysis cluster fish hepcidins $1 \& 2$ of Perciformes and Pleuronectiformes together separated from other vertebrate hepcidins. Additionally, Campoverde et al. (2017) found that the phylogenetic analysis revealed that meager hep2 sequence was more similar to that of Larimichthys crocea. Even though, there are antithesis opinions suggesting that progression and divergence of hepcidin antimicrobial peptide is connected with their surrounding habitats and pathogens.
This study reported that the three-dimensional structure of hepcidin 1 and hepcidin 2 shows it to be an amphipathic molecule composed of two distorted antiparallel $\beta$-sheets separated by a hairpin loop, containing a vicinal disulfide bond (disulfide bond between adjacent cysteines), and stabilized by three inter- $\beta$-sheet disulfide bonds and signal peptide is detected from 1 to 4 amino acids which remarkably similar among $O$. niloticus, T. zillii, and S. galilaeus species. Xu et al. (2008) demonstrated that lower vertebrates have very similar

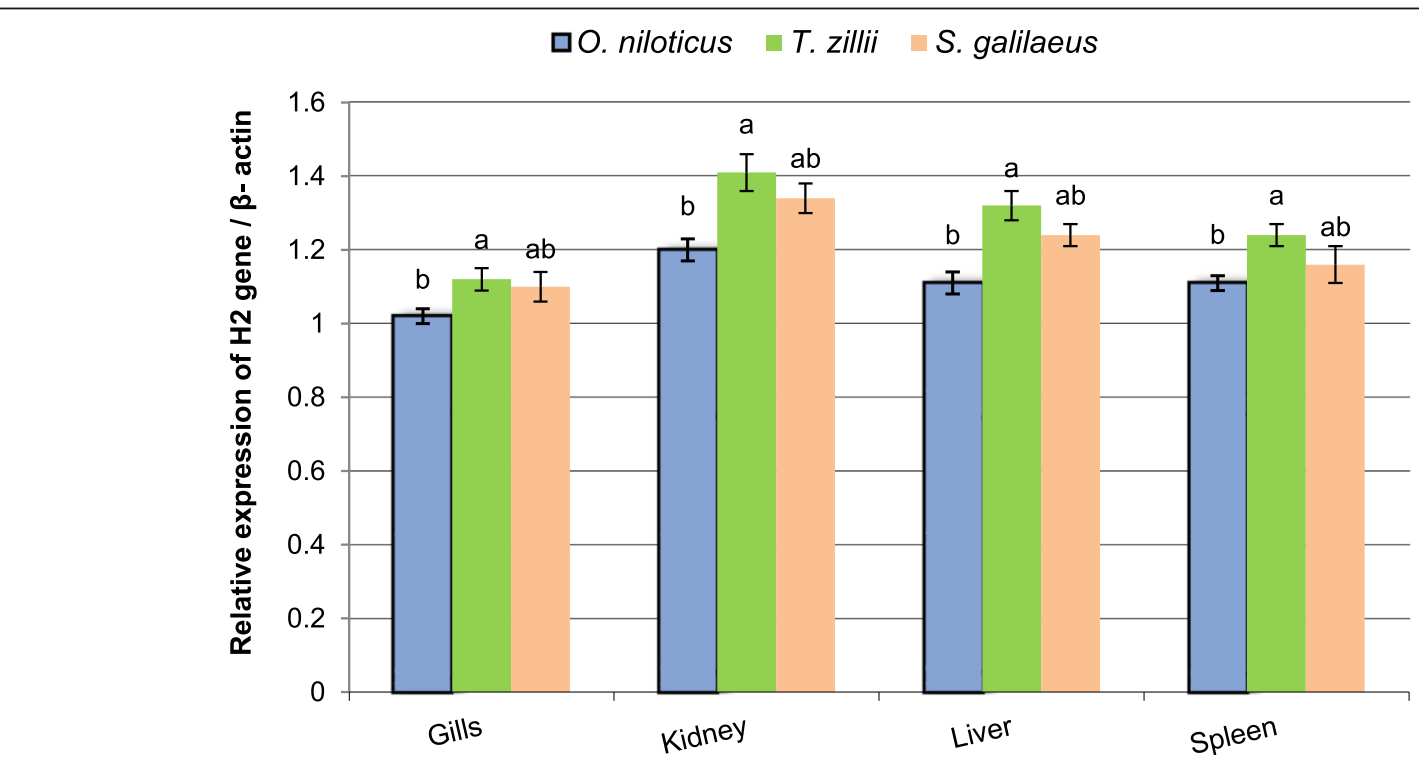

Fig. 13 Expression levels of some antimicrobial peptide gene hepcidin $2(\mathrm{H} 2)$ in different tissues of O. niloticus, T. zillii and S. galilaeus. Data are presented as mean \pm SEM. ${ }^{a, b}$ followed by different superscripts are significantly different $(P \leq 0.05)$ 
structures of hepcidin homologs (20-25aa) with eight highly conserved cysteines and four intramolecular disulfide bonds, giving hepcidin a hairpin structure. Tilapia fish Oreochromis mossambicus (Huang et al. 2007) and schizothorax richardsonii (Gray) (Chaturvedi et al. 2014) presented the same results. Previous studies by Zhang et al. (2009), Wang et al. (2010), and Chen et al. (2009) demonstrated that hepcidin hairpin structure with cationic residual act against fungi, bacteria, tumor cells, and viruses. Hepcidin hairpin-like structure are considered to be essential for its activity (Neves et al. 2015).

Regarding gene expression results, this study found that expression levels of $\mathrm{H} 1$ and $\mathrm{H} 2$ genes were increased in gills, kidney, and liver tissues of $O$. niloticus, T. zillii, and S. galilaeus naturally infected with bacteria in the Lake Manzala. However, the expression levels of $\mathrm{H} 1$ and $\mathrm{H} 2$ genes were decreased in spleen tissues. In the same line with our findings, several studies found that in many fish species and other vertebrates (Krause et al. 2000; Park et al. 2001; Zhou et al. 2011; Li et al. 2013; Chen et al. 2007; Rodrigues et al. 2006), both sea bass $\mathrm{H} 1$ and $\mathrm{H} 2$ genes were abundantly expressed in the liver. Additionally, they also reported that the expression levels of $\mathrm{H} 1$ and $\mathrm{H} 2$ genes were very low in the spleen. Hepcidin expression has been reported to have an important role in macrophages, lymphocytes, and monocytes but further analysis will be required to determine the exact cells responsible for this expression (Costa et al. 2011; Sow et al. 2007; Zhang and Rovin 2010; Pinto et al. 2010). The higher antimicrobial potential of $\mathrm{H} 1$ and $\mathrm{H} 2$ genes were observed in this study with over-expression in gills. That could be explained because these tissues are in constant contact with the surrounding environment, many times a doorway to microbial infection.

The present study found that strain of fish including O. niloticus, T. zillii, and S. galilaeus were naturally infected with bacteria in the Lake Manzala. The O. niloticus strain was infected with Aeromonas hydrophila but T. zillii and S. galilaeus were infected by Pseudomonas luteola. Several studies reported that both $\mathrm{H} 1$ and $\mathrm{H} 2$ genes were upregulated in fish with bacterial infections (Hirono et al. 2005; Huang et al. 2007). A significant induction of both sea bass $\mathrm{H} 1$ and $\mathrm{H} 2$ gene types was observed after experimental bacterial challenge with $P$. damselae spp. piscicida.

Additionally, it has been reported that $\mathrm{H} 1$ and $\mathrm{H} 2$ genes may have antimicrobial activity even so the initial pathogen density is very low (4. $3103 \mathrm{CFU} / \mathrm{ml}$ ) (Zhang et al. 2014). Moreover, $\mathrm{H} 1$ and $\mathrm{H} 2$ peptides manifested strong antimicrobial activities against Gram-positive bacteria. Further studies will be required to better understand the relevance of each type of hepcidin genes and to gain insight into their antimicrobial properties.

\section{Conclusions}

The results concluded that the hepcidin 1 and 2 genes showed constitutive expressions in most of tested tissues and have a very similar three-dimensional structure as well as mature peptides which mean that these genes are highly conserved within the species examined.

\section{Abbreviations \\ Hepc1: Hepcidin 1; Hepc2: Hepcidin 2; T. zillii : Tilapia zillii; S. \\ galilaeus: Sarotherodon galilaeus; O. niloticus: Oreochromis niloticus; \\ HAMP1: Hepcidin Antimicrobial peptide 1; HAMP2: Hepcidin Antimicrobial peptide 2; CDNA: Complementary DNA; AMPs: Antimicrobial peptides; $\beta$ - actin: Beta actin; CD: Coding region; aa: Amino acid; mRNA: Messenger RNA; RT-PCR: Real time -polymerase chain reaction}

\section{Acknowledgements \\ This study was financially supported by the Science and Technology Development Fund (STDF), Egypt (Grant number: 15153). \\ We thank Noha M. Osman who carried out the sequence data analysis and statistical analysis.}

\section{Authors' contributions}

KFM contributed her idea, designed the experiments, co-wrote the paper, and supervised the research. HAMAK performed the experiments and cowrote the paper. DMM performed the experiments and co-wrote the paper. MMA designed the primers and performed the experiments. NMO performed the bioinformatic and statistical analyses. WKB Khalil performed the experiments and co-wrote the paper. Hassanane M. S supervised the research. All authors contributed to the study design, laboratory analysis, and writing of the manuscript. All authors revised the final manuscript and approved it.

\section{Funding}

The work was funded by the Science and Technology Development Fund (STDF), Egypt (Grant number: 15153).

\section{Availability of data and materials}

All data generated or analyzed during this study are included in this published article

\section{Ethics approval and consent to participate}

The study was approved by the ethical committee of the National Research Centre

\section{Consent for publication}

Not applicable

\section{Competing interests}

The authors declare that they have no competing interests.

Received: 26 October 2019 Accepted: 3 February 2020

Published online: 06 March 2020

\section{References}

Asmamaw B (2016) Hepcidin and Its Roles in Fishes. The Journal of Zoology Studies. 3(3):1-10

Ausubel FM, Brent R, Kingston RE, Moore DD, Seidman JG, Smith JA, Kevin S. Current Protocols in Molecular Biology In: the polymerase chain reaction K. B. Mullis, F. Ferre, R.A. Gibbsditors. 1990 (eds.)

Bao B, Peatmana E, Xua P, Lia P, Zenga H, Hea C, Liua BZ (2006) The catfish liverexpressed antimicrobial peptide2 (LEAP-2) gene is expressed in a wide range of tissues and developmentally regulated Baolong. Mol Immunol 43:367-377

Bian C, Li J, Lin X, Chen X, Yi Y, You X, Zhang Y, Lv Y, Shi Q (2019) Whole genome sequencing of the blue tilapia (Oreochromis aureus) provides a valuable genetic resource for biomedical research on tilapias. Mar Drugs. 17:386

Campoverdea C, Douglas J, Milne B, Est A, Evez A, Neil D, Christopher JS, Karl BA (2017) Ontogeny and modulation after PAMPs stimulation of b-defensin, hepcidin, and piscidin antimicrobial peptides in meagre (Argyrosomu sregius). Fish \& Shellfish Immunology. 69:200-210 
Chaturvedi PX, Dhanik M, Pande A (2014) Characterization and structural analysis of hepcidin like antimicrobial peptide from schizothorax richardsonii (Gray). Protein J. 33:1-10

Chen JY, Lin WJ, Lin TL (2009) A fish antimicrobial peptide, tilapia hepcidin TH2-3, shows potent antitumor activity against human fibrosarcoma cells. Peptides. 30:1636-1642

Chen SL, Li W, Meng L, Sha ZX, Wang ZJ, Ren GC (2007) Molecular cloning and expression analysis of a hepcidin antimicrobial peptide gene from turbot (Scophthalmus maximus). Fish Shellfish Immunology. 22:172-181

Costa MM, Maehr T, Diaz-Rosales P, Secombes CJ, Wang T (2011) Bioactivity studies of rainbow trout (Oncorhynchus mykiss) interleukin-6: effects on macrophage growth and antimicrobial peptide gene expression. Molecular Immunology. 48:1903-1916

Douglas SE, Gallant JW, Liebscher RS, Dacanay A, Tsoi SCM (2003) Identification and expression analysis of hepcidin-like antimicrobial peptides in bony fish Developmental Comparative Immunol. 27:589-601

Falzacappa MW, Muckenthaler MU (2005) Hepcidin: Iron-hormone and antimicrobial peptide. Gene. 364:37-44. https://doi.org/10.1016/j.gene..07.020

Ganz T (2003) Hepcidin, a key regulator of iron metabolism and mediator of anemia of inflammation. Blood. 102(3):783-788

Ganz T (2007) Molecular control of iron transport. Journal of the American Society of Nephrology. 18:394-400

Hirono I, Hwang JY, Ono Y, Kurobe T, Ohira T, Nozaki R, Aoki T (2005) Two different types of hepcidins from the Japanese flounder Paralichthys olivaceus. Fedration Eurobean Biochemical Societies J. 272:5257-5264

Hsieh JC, Pan CY, Chen JY (2010) Tilapia hepcidin (TH)2-3 as a transgene in transgenic fish enhances resistance to Vibrio vulnificus infection and causes variations in immune-related genes after infection by different bacterial species. Fish \& Shellfish Immunology. 29:430-439

Hu X, Camus AC, Aono S, Morrison EE, Dennis J, Nusbaum KE et al (2007) Channel catfish hepcidin expression in infection and anemia. Comparative Immunology, Microbiolology of Infectious Diseases. 30:55-69. https://doi.org/ 10.1016/j.cimid.2006.10.004

Huang PH, Chen JY, Kuo CM (2007) Three different hepcidins from tilapia, Oreochromis mossambicus: Analysis of their expressions and biological functions. Molecular Immunology. 44(8):1922-1934

Jain A, Yadav BK, Chugh A (2015) Marine antimicrobial peptide tachyplesin as an efficient nanocarrier for macromolecule delivery in plant and mammalian cells. FEBS J. 282:732-745

Jenssen H, Hamill P, Hancock REW (2006) Peptide antimicrobial agents. Clin Microbiol Rev. 19(3):491-451

Krause AS, Neitz HJ, Mägert A, Schulz WG, Forssmann P, Schulz-Knappe, Adermann K (2000) LEAP-1, a novel highly disulfide-bonded human peptide, exhibits antimicrobial activity. FEBS Lett 480:147-150

Kumar S, Stecher G, Li M, Knyaz C, Tamura K (2018) MEGA X: molecular evolutionary genetics analysis across computing platforms. Mol. Biol. Evol. 35(6):1547-1549

Lauth X, Babon JJ, Stannard JA, Singh S, Nizet V, Carlberg JM et al (2005) Bass hepcidin synthesis, solution structure, antimicrobial activities and synergism, and in vivo hepatic response to bacterial infections. J. Biological Chem. 280(10):9272-9282

Lee J, Wan K, Adnan A (2012) Molecular characterization of hepcidin in the Asian seabass (Lates calcarifer) provides insights into its role in innate immune response. Aquaculture. 330:8-14

Li H, Zhang F, Guo H, Zhu Y, Yuan J, Yang G, An L (2013) Molecular charac- terization of hepcidin gene in common carp (Cyprinus carpio L.) and its expression pattern responding to bacterial challenge. Fish Shellfish Immunol. 35:1030-1038

Martin-Antonio B, Jiménez-Cantizano RM, Salas-Leiton E, Infante C, Manchado M (2009) Genomic characterization and gene expression analysis of four hepcidin genes in the Red banded seabream (Pagrus auriga). Fish Shellfish Immunol. 26(3):483-491

Masso-Silva JA, Diamond G (2014) Antimicrobial peptides from fish Pharmaceuticals (Basel). 7(3):265-310. https://doi.org/10.3390/ph7030265

Neves JV, Caldas C, Vieira I, Ramos MF, Rodrigues PN (2015) Multiple hepcidins in a teleost fish, Dicentrarchus labrax: different hepcidins for different roles. J Immunol. 195(6):2696-2709

Noga EJ (1996) Fish disease: diagnosis and treatment. Moshy-Year book, Inc, Naples, Tokyo, New York, p 294

Park CH, Valore EV, Waring AJ, Ganz T (2001) Hepcidin, a urinary antimicrobial peptide synthesized in the liver. J Biogiological Chem. 276:7806-7810
Pinto JP, Dias V, Zoller H, Porto G, Carmo H, Carvalho F, Sousa M (2010) Hepcidin messenger RNA expression in human lymphocytes. Immunology. 130:217-230

Pridgeon JW (2012) Expression profiles of seven channel catfish antimicrobial peptides in response to Edwardsiella ictaluri infection. J Fish Dis. 35:227-237

Rajanbabu V, Chen JY (2011) Applications of antimicrobial peptides from fish and perspectives for the future. Peptides 32:415-e420. https://doi.org/10.1016/j. peptides...11.005

Rodrigues PN, Va'zquez-Dorado S, Neves JV, Wilson JM (2006) Dual function of fish hepcidin: response to experimental iron overload and bacterial infection in sea bass (Dicentrarchus labrax). Developmental. Comparative. Immunology. 30:1156-1167

Ruijter JM, Ramakers C, Hoogaars WMH, Karlen Y, Bakker O, Hoff MJB, Moorman AFM (2009) Amplification efficiency: linking baseline and bias in the analysis of quantitative PCR data. Nucleic Acids Res. 37:45

Saitou N, Nei M (1987) The neighbor-joining method: a new method for reconstructing phylogenetic trees. Mol Biol Evol. 4(4):406-425

Shi J, Camus AC (2005) Hepcidins in amphibians and fishes: Antimicrobial peptides or iron-regulatory hormones? Developmental Comparative Immunology 30:746-755. https://doi.org/10.1016/j.dci.10.009

Silva JM, Gill Diamond B, Maria Macias-Rodriguez A, Ascencio F (2011) Genomic organization and tissue-specific expression of hepcidin in the pacific mutton hamlet, Alphestes immaculatus (Breder, 1936). Fish Shellfish Immunol. 31 1297-1302

Sow FB, Florence WC, Satoskar AR, Schlesinger LS, Zwilling BS, Lafuse WP (2007) Expression and localization of hepcidin in macrophages: a role in host defense against tuberculosis. J Leukocytic Biol. 82:934-945

Thompson JD, Higgins DG, Gibson TJ (1994) CLUSTAL W: improving the sensitivity of progressive multiple sequence alignment through sequence weighting, position-specific gap penalties and weight matrix choice. Nucleic acids research. 22(22):4673-4680

Wang Y, Liu X, Ma L, Yu Y, Yu H, Mohammed S et al (2012) Identification and characterization of a hepcidin from half-smooth tongue sole Cynoglossus semilaevis. Fish Shellfish Immunol. 33:213-219. https://doi.org/10.1016/j.fsi. 2012.04.011

Wang YD, Kung CW, Chen JY (2010) Antiviral activity by fish antimicrobia peptides of epinecidin-1 and hepcidin 1-5 against nervous necrosis virus in medaka. Peptides. 31(6):1026-1033

Xu Q, Cheng CH, Hu P, Ye H, Chen Z, Cao L, Chen L, Shen Y, Chen L (2008) Adaptive evolution of hepcidin genes in antarctic notothenioid fishes. Mol Biol Evol. 25:1099-1112

Xu T, Sun Y, Shi G, Wang R (2012) Miiuy croaker hepcidin gene and comparative analyses reveal evidence for positive selection. PLoS One. 7(4):35449

Zhang J, Yan Q, Ji R, Zou W, Guo G (2009) Isolation and characterization of a hepcidin peptide from the head kidney of large yellow croaker, Pseudosciaena crocea. Fish Shellfish Immunol. 26:864-870

Zhang X, Rovin BH (2010) Hepcidin expression by human monocytes in response to adhesion and pro-inflammatory cytokines. Biochemistry Biophysics Acta 1800(12):1262-1267

Zhang J, Yu LP, Li MF, Sun L (2014) Turbot (Scophthalmus maximus) hepcidin-1 and hepcidin-2 possess antimicrobial activity and promote resistance against bacterial and viral infection. Fish Shellfish Immunol. 38(1):127-134

Zhou JG, Wei JG, Xu D, Cui HC, Yan Y, Ou-Yang ZL, Huang XH, Huang YH, Qin QW (2011) Molecular cloning and characterization of two novel hepcidins from orange-spotted grouper, Epinephelus coioides. Fish Shellfish Immunol. 30:559-568

\section{Publisher's Note}

Springer Nature remains neutral with regard to jurisdictional claims in published maps and institutional affiliations. 